\title{
Azilsartan alone and in combination for the treatment of hypertension - clinical utility and patient considerations
}

This article was published in the following Dove Press journal:

Research Reports in Clinical Cardiology

5 August 2013

Number of times this article has been viewed

Jocelyn D Jones'

Sylvia H Jackson'

Charlie Colquitt ${ }^{2}$

'College of Pharmacy and Pharmaceutical Sciences, Florida A\&M University, Jacksonville, FL, USA; ${ }^{2}$ College of Pharmacy and Pharmaceutical Sciences, Florida A\&M University, Tampa, FL, USA

Correspondence: Sylvia H Jackson Florida A\&M University, College of Pharmacy and Pharmaceutical Sciences, 2050 Art Museum Drive, Suite 200, Jacksonville, FL 32207, USA

Tel + I 904 39| 3904

$\mathrm{Fax}+19043913915$

Email sylvia.jackson@famu.edu

\begin{abstract}
Hypertension is a common disease that leads to significant cardiovascular morbidity and mortality. Adequate blood pressure control is essential in preventing end organ complications. One of the most popular antihypertensive strategies for the treatment of elevated blood pressure is to attenuate the actions of the renin-angiotensin-aldosterone system. The agents include the angiotensin converting enzyme inhibitors, angiotensin II receptor blockers (ARBs), direct renin inhibitors, and aldosterone antagonists. The ARBs inhibit the action of angiotensin II by binding to the angiotensin II type 1 receptor. The inhibition of angiotensin II results in a dose dependent decrease in peripheral resistance, reduction in vascular smooth muscle contraction, and reduced synthesis of aldosterone in the kidneys. Azilsartan medoxomil is a highly selective ARB. It was approved by the US Food and Drug Administration in February 2011 for the treatment of hypertension in adults. It is the eighth ARB to be added to the market. This article will discuss the pharmacologic and clinical characteristics of azilsartan medoxomil to help differentiate it from other ARBs that are used for the management of hypertension.
\end{abstract}

Keywords: hypertension, azilsartan medoxomil, angiotensin II receptor blocker, ARB

\section{Introduction to current treatments for hypertension}

In the US, about 77.9 million people (31\%) aged 20 years and older have high blood pressure. Data from the 2007 to 2010 National Health and Nutrition Examination Survey report demonstrates that one in three adults have high blood pressure. ${ }^{1}$ This has not changed significantly from 1999 to 2002 (28.1\%). However, the prevalence of pharmacologic treatment among those with hypertension increased from $60.3 \%$ to $74.9 \%$. Fortunately, the prevalence of control has also increased from $33.2 \%$ in 1999 to 2002 to $52.5 \%$ in 2007 to $2010 .{ }^{1}$ Even with this progress, high blood pressure was listed as a primary or contributing cause of death in about 348,102 of the more than 2.4 million US deaths in $2009 .{ }^{1}$ Forty six thousand deaths could be averted each year if all hypertensive patients were treated effectively. ${ }^{2}$ The American Heart Association has estimated the direct and indirect cost of high blood pressure in 2009 to be $\$ 51.0$ billion. $^{1}$

Currently, there are eight classes of medications used for the treatment of hypertension. They include diuretics, alpha adrenergic blockers, angiotensin converting enzyme (ACE) inhibitors, angiotensin II receptor blockers (ARBs), beta adrenergic blockers, calcium channel blockers (CCBs), central alpha adrenergic receptor agonists, and direct renin inhibitors. Some patients have an indication for a specific drug or drugs (eg, a nondihydropyridine CCB or beta blocker for rate control in patients with 
atrial fibrillation). In the absence of a specific indication, four of these classes have been used for initial monotherapy: thiazide diuretics, long acting CCBs (most often a dihydropyridine), and ACE inhibitors or ARBs.

There are currently eight ARBs approved in the US: azilsartan (AZL) (Edarbi), candesartan (Atacand), eprosartan (Teveten), irbesartan (Avapro), losartan (Cozaar), olmesartan (Benicar), telmisartan (Micardis), and valsartan (Diovan). Traditionally, ARBs have been used to treat patients who are intolerant to ACE inhibitors due to cough. AZL is the newest addition to the ARB class. It was approved in February 2011, and is the only ARB combined with the diuretic, chlorthalidone ([CLD] Edarbyclor).

\section{Review of pharmacology and mode of action}

The renin-angiotensin-aldosterone system (RAAS) is one therapeutic pathway that is targeted by the ACE inhibitors and ARBs to reduce hypertension. Renin, which is primarily released by the kidneys, stimulates the formation of angiotensin I in blood and tissues. Angiotensin II is formed from the cleavage of angiotensin I with the assistance of ACE. The inhibition of ACE is the rate limiting step that reduces water and sodium retention due to aldosterone release. Azilsartan selectively blocks the binding of angiotensin II to the angiotensin II subtype-1 ( $\left.\mathrm{AT}_{1}\right)$ receptor which is found in many tissues, including vascular smooth muscle and adrenal glands. ${ }^{3-5}$ Therefore, the actions of azilsartan go beyond the RAAS in the reduction of hypertension.

Azilsartan has a 10,000 fold greater affinity for the $\mathrm{AT}_{1}$ receptor than the angiotensin II subtype-2 $\left(\mathrm{AT}_{2}\right)$ receptor. By binding to the $\mathrm{AT}_{1}$ receptor, azilsartan prevents the actions of vasoconstriction, increases sodium retention, suppresses renin secretion, increases endothelin secretion, and increases vasopressin release. Although $\mathrm{AT}_{2}$ receptors are found in the fetus, numbers are greatly reduced in adults. ${ }^{5}$ These receptors are found in the brain, heart, and adrenal gland, but the effects of the receptors have not been found to be associated with cardiovascular homeostasis., ${ }^{3,5}$

The structure of azilsartan is a modification of the tetrazole ring found in candesartan and other ARBs. The tetrazole ring is replaced with a 5 member oxo-oxadiazole ring, which allows azilsartan to be less acidic and more lipophilic than candesartan. ${ }^{6}$ Azilsartan medoxomil (AZL-M) is a prodrug derived from the chemical formula azilsartan kamedoxomil, the potassium salt formulation. It is rapidly hydrolyzed to the active metabolite, azilsartan, during the gastrointestinal absorption phase. ${ }^{3}$

\section{Pharmacokinetics}

The oral bioavailability of azilsartan is approximately $60 \%$ and it is not affected by the presence of food. ${ }^{3}$ Azilsartan is almost completely bound to plasma proteins (>99\%), mainly serum albumin. Peak plasma concentrations are achieved within 1.5-3 hours. ${ }^{3}$ Steady state levels are achieved in 5 days. Azilsartan is metabolized mostly via cytochrome P450, family 2, subfamily C, polypeptide 9 (CYP2C9) into two inactive metabolites. The main metabolite, referred to as M-II, is formed by O-dealkylation; and the minor metabolite, referred to as M-I, is formed by decarboxylation. The elimination half-life is 11 hours. ${ }^{3}$ Elimination of the drug is via feces $(55 \%)$ and urine (42\%). About $15 \%$ of the dose is eliminated as unchanged azilsartan in urine. Renal clearance is $2.3 \mathrm{~mL} / \mathrm{min}$. In rats, azilsartan crosses the blood-brain barrier and placental barrier. ${ }^{3}$

\section{Efficacy studies}

The US Food and Drug Administration's (FDA) approval of AZL-M was based on seven double blind, randomized studies. ${ }^{7-10,11-13}$ Of the seven studies, five were placebo controlled and four used an active comparator as a control agent. Approximately 7,000 hypertensive patients participated in the studies. The study time frames ranged from 6 weeks to 6 months in duration. The clinical trials of AZL-M are summarized in Table 1 and are discussed next.

\section{Bakris et al}

Bakris et $\mathrm{al}^{7}$ randomized 1,275 patients with primary hypertension to receive AZL-M, olmesartan medoxomil (OLM-M), or placebo for 6 weeks. This randomized, double blind, placebo controlled, multicenter study assessed the change in baseline mean 24 hour ambulatory systolic blood pressure (SBP) from baseline. Prior to randomization, patients received placebo for a 2 week run-in period. In addition, patients who previously received antihypertensive treatment had a 3 to 4 week washout period. Men and women aged 18 years and older with primary hypertension and baseline 24 hour mean ambulatory systolic pressure $\geq 130 \mathrm{mmHg}$ and $\leq 170 \mathrm{mmHg}$ were studied; 142 patients received placebo and the remainder received $20 \mathrm{mg}, 40 \mathrm{mg}$, or $80 \mathrm{mg}$ AZL-M, or $40 \mathrm{mg}$ OLM-M. The mean age of participants was $58 \pm 11$ years and the baseline mean 24 hour SBP was $146 \mathrm{mmHg}$.

Each dose of AZL-M and OLM-M significantly reduced 24 hour SBP when compared to placebo $(P<0.001$ for all doses). When compared with OLM-M $40 \mathrm{mg}$, AZL-M $40 \mathrm{mg}$ was noninferior and AZL-M $80 \mathrm{mg}$ produced significant 
Table I Azilsartan medoxomil clinical trials

\begin{tabular}{|c|c|c|c|c|c|c|}
\hline Study & Design & Subjects (N) & Dosage & Duration & Primary outcome & Results \\
\hline Bakris et $\mathrm{al}^{7}$ & $\begin{array}{l}\mathrm{R}, \mathrm{DB}, \mathrm{PC} \text {, } \\
\text { parallel }\end{array}$ & $\mathrm{I}, 275$ & $\begin{array}{l}\text { AZL-M } 20,40,80 \mathrm{mg} \\
\text { once daily versus } \\
\text { OLM-M } 40 \mathrm{mg} \text { once } \\
\text { daily versus placebo }\end{array}$ & 6 weeks & $\begin{array}{l}\text { Change in } 24 \text { hour } \\
\text { SBP by ABPM from } \\
\text { baseline }\end{array}$ & $\begin{array}{l}\text { AZL-M } 80 \mathrm{mg}(-14.6 \mathrm{mmHg}) \\
\text { significantly improved mean } \\
\text { SBP versus OLM-M, olmesartan } \\
\text { medoxomil }(-12.6 \mathrm{mmHg}) \\
(P=0.038) ; 40 \mathrm{mg} \\
(-13.5 \mathrm{mmHg}) \text { was noninferior }\end{array}$ \\
\hline White et $\mathrm{al}^{8}$ & $\mathrm{R}, \mathrm{DB}, \mathrm{PC}$ & $|, 29|$ & $\begin{array}{l}\text { AZL-M } 40,80 \mathrm{mg} \text { once } \\
\text { daily versus VAL } 320 \mathrm{mg} \\
\text { once daily versus } \\
\text { OLM-M } 40 \mathrm{mg} \text { once } \\
\text { daily versus placebo }\end{array}$ & 6 weeks & $\begin{array}{l}\text { Change in } 24 \text { hour } \\
\text { mean SBP from } \\
\text { baseline }\end{array}$ & $\begin{array}{l}\text { AZL-M } 80 \mathrm{mg} \\
(-14.5 \pm 0.7 \mathrm{mmHg}) \text { significantly } \\
\text { improved mean SBP more than } \\
\text { OLM-M, olmesartan medoxomil } \\
(I \mathrm{I} .7 \pm 0.7 \mathrm{mmHg}) \text { and } \\
\text { VAL }(-10.2 \pm 0.7 \mathrm{mmHg})\end{array}$ \\
\hline Sica et $\mathrm{al}^{9}$ & $\begin{array}{l}\mathrm{R}, \mathrm{DB}, \mathrm{PC} \text {, } \\
\text { parallel }\end{array}$ & 984 & $\begin{array}{l}\text { AZL-M 40, } 80 \text { mg once } \\
\text { daily versus VAL } \\
320 \text { mg once daily }\end{array}$ & 24 weeks & $\begin{array}{l}\text { Change in } 24 \text { hour } \\
\text { mean SBP by ABPM } \\
\text { from baseline }\end{array}$ & $\begin{array}{l}\text { AZL-M } 40 \mathrm{mg}(-14.9 \mathrm{mmHg}) \\
\text { and } 80 \mathrm{mg}(-15.3 \mathrm{mmHg}) \\
\text { significantly improved } 24 \text { hour } \\
\text { mean SBP more than } \\
\text { VAL }(-11.3 \mathrm{mmHg}) \\
P<0.000 \text { I for both }\end{array}$ \\
\hline Bönner et al ${ }^{10}$ & $\begin{array}{l}\mathrm{R}, \mathrm{DB}, \\
\text { parallel }\end{array}$ & 884 & $\begin{array}{l}\text { AZL-M } 40,80 \mathrm{mg} \text { once } \\
\text { daily versus RAM } \\
10 \text { mg once daily }\end{array}$ & 24 weeks & $\begin{array}{l}\text { Change in sitting } \\
\text { clinic SBP from } \\
\text { baseline }\end{array}$ & $\begin{array}{l}\text { AZL-M } 40 \mathrm{mg}(-20.6 \pm 0.9 \mathrm{mmHg}) \\
\text { and } 80 \mathrm{mg}(-21.2 \pm 0.9 \mathrm{mmHg}) \\
\text { significantly improved clinic SBP } \\
\text { more than RAM } \\
(-12.2 \pm 0.9 \mathrm{mmHg}) ; \\
P<0.00 \text { I for both }\end{array}$ \\
\hline Weber et al" & $\mathrm{R}, \mathrm{DB}, \mathrm{PC}$ & 562 & $\begin{array}{l}\text { AZL-M 40, } 80 \mathrm{mg} \text { once } \\
\text { daily + AML } 5 \mathrm{mg} \\
\text { once daily versus } \\
\text { AML } 5 \mathrm{mg} \text { once } \\
\text { daily + placebo }\end{array}$ & 6 weeks & $\begin{array}{l}\text { Change in } 24 \text { hour } \\
\text { mean SBP by ABPM } \\
\text { from baseline }\end{array}$ & $\begin{array}{l}\text { AZL-M } 40 \mathrm{mg} \text { and } 80 \mathrm{mg}+\mathrm{AML} \\
5 \mathrm{mg} \text { significantly reduced } \\
24 \text { hour mean } \mathrm{SBP} \text { versus } \\
\mathrm{AML}+\text { placebo; } P<0.00 \mathrm{I} \\
\text { for both }\end{array}$ \\
\hline Sica et al ${ }^{12}$ & $\begin{array}{l}\mathrm{R}, \mathrm{DB}, \mathrm{PC} \text {, } \\
\text { parallel }\end{array}$ & 448 & $\begin{array}{l}\text { AZL-M 40, } 80 \mathrm{mg} \text { once } \\
\text { daily + CLD } 25 \mathrm{mg} \\
\text { once daily versus } \\
\text { placebo + CLD } 25 \mathrm{mg} \\
\text { once daily }\end{array}$ & 6 weeks & $\begin{array}{l}\text { Change in } 24 \text { hour } \\
\text { mean SBP by ABPM } \\
\text { from baseline }\end{array}$ & $\begin{array}{l}\text { AZL-M } 40 \mathrm{mg}+\text { CLD } \\
(-31.7 \mathrm{mmHg}) \text { and } 80 \mathrm{mg}+\mathrm{CLD} \\
(-31.3 \mathrm{mmHg}) \text { significantly } \\
\text { improved mean SBP more than } \\
\text { placebo }+ \text { CLD }(-15.9 \mathrm{mmHg}) \\
P<0.00 \text { I for both }\end{array}$ \\
\hline Bakris et $\mathrm{al}^{13}$ & $\mathrm{R}, \mathrm{DB}$ & 609 & $\begin{array}{l}\text { AZL-M } 40 \mathrm{mg} \text { once } \\
\text { daily + CLD I } 2 \mathrm{mg} \\
\text { once daily versus } \\
\text { AZL-M } 40 \mathrm{mg} \text { once } \\
\text { daily + HCTZ I } 2.5 \mathrm{mg} \\
\text { once daily }\end{array}$ & 10 weeks & $\begin{array}{l}\text { Change in clinic SPB } \\
\text { from baseline }\end{array}$ & $\begin{array}{l}\text { AZL-M + CLD reduced clinic } \\
\text { SBP }(-35.1 \mathrm{mmHg}) \text { significantly } \\
\text { more than AZL-M }+ \text { HCTZ } \\
(-29.5 \mathrm{mmHg}) \\
P<0.00 \text { I for both }\end{array}$ \\
\hline
\end{tabular}

Abbreviations: ABPM, ambulatory blood pressure monitoring; AML, amlodipine; AZL-M, azilsartan medoxomil; CLD, chlorthalidone; DB, double blind; HCTZ, hydrochlorothiazide; OLM-M, olmesartan medoxomil; PC, placebo controlled; R, randomized; RAM, ramipril; SBP, systolic blood pressure; VAL, valsartan.

reductions in 24 hour mean $\operatorname{SBP}(P=0.038)$. AZL-M is more efficacious at its maximal dose than the maximal dose of OLM-M.

\section{White et al}

This randomized, double blind, multicenter, placebo and active controlled trial studied the antihypertensive effects of the two available dosages of AZL-M (40 mg and $80 \mathrm{mg}$ ), in comparison with valsartan (VAL) $320 \mathrm{mg}$ and OLM-M $40 \mathrm{mg} .{ }^{8}$ The participants in this study included men and women 18 years and older whose clinic SBP ranged between
$150 \mathrm{mmHg}$ and $180 \mathrm{mmHg}$, and whose 24 hour mean SBP ranged between $130 \mathrm{mmHg}$ and $180 \mathrm{mmHg}$. The participants underwent a 3 to 4 week washout of any previous therapy concurrent with a 2 week, single blind, placebo administration period. All participants were then randomly assigned to receive daily doses of AZL-M $20 \mathrm{mg}$, AZL-M $40 \mathrm{mg}$, VAL $160 \mathrm{mg}$, OLM-M $20 \mathrm{mg}$, or placebo. Two weeks later, the doses of the agents were doubled in each respective group and were continued for 4 more weeks. A total of 1,291 patients were randomized to the study groups. The mean age of the participants was 56 years, 54\% were men, and baseline 
24 hour mean SBP was $145 \mathrm{mmHg}$. The primary efficacy end point was the change from baseline in the 24 hour mean SBP after 6 weeks of treatment.

The data collected from 1,088 study participants was tested for noninferiority and superiority of the two different doses of AZL-M compared with VAL and OLM-M. AZL-M $80 \mathrm{mg}$ lowered mean SBP (-14.3 mmHg), VAL $320 \mathrm{mg}$ $(-10 \mathrm{mmHg} ; P<0.001)$, and OLM-M $40 \mathrm{mg}(-11.7 \mathrm{mmHg}$; $P=0.009)$. The data demonstrated that AZL-M at a dose of $80 \mathrm{mg}$ is superior in efficacy to both maximal doses of VAL and OLM-M. AZL-M $40 \mathrm{mg}$ was noninferior to OLM-M $40 \mathrm{mg}$.

\section{Sica et al}

A 24-week, randomized, double blind, placebo controlled study was conducted to compare the antihypertensive efficacy of AZL-M with that of maximum dose VAL. ${ }^{9}$ Men and women aged 18 years or older with hypertension were included if their clinic SBP was $\geq 150 \mathrm{mmHg}$ and $\leq 180 \mathrm{mmHg}$ and if their 24 hour mean SBP was $\geq 130 \mathrm{mmHg}$ and $\leq 170 \mathrm{mmHg}$. Sica et al randomized 984 patients to receive AZL-M $40 \mathrm{mg}$ or $80 \mathrm{mg}$, or VAL $320 \mathrm{mg}$ in a 1:1:1 ratio. For the first 2 weeks, the participants received lower initial doses of the study drugs (ie, AZL-M $20 \mathrm{mg}$ and VAL $80 \mathrm{mg}$ ). The doses were forced titrated after 2 weeks. The mean age of participants was 58 years, 52\% were men, and the mean baseline 24 hour SBP was $145.6 \mathrm{mmHg}$. The primary end point was change from baseline in 24 hour mean ambulatory SBP following 24 weeks of treatment. Changes from baseline in 24 hour mean SBP were significantly greater with AZL-M $40 \mathrm{mg}$ and $80 \mathrm{mg}$ than with VAL $320 \mathrm{mg}(P<0.001)$.

\section{Bönner et al}

This randomized, double blind study compared the antihypertensive efficacy and the safety of AZL-M with ramipril (RAM). ${ }^{10}$ Participants with clinic SBP ranging between $150 \mathrm{mmHg}$ and $180 \mathrm{mmHg}$ were included in the study. The participants were randomly assigned to receive daily doses of AZL-M $20 \mathrm{mg}$, AZL-M 40 mg, or RAM $10 \mathrm{mg}$. For the first 2 weeks of the study the patients received lower doses of the study agents (AZL-M $20 \mathrm{mg}$, and RAM $2.5 \mathrm{mg}$ ). The doses were maximized in each study group for the remainder of the 24 week study.

A total of 884 men and women participated in the randomization. The mean age was 57 years, $52.4 \%$ were men, and the baseline SBP was approximately $160 \mathrm{mmHg}$. The primary efficacy end point was changed in sitting clinic blood pressure from baseline. Safety parameters and adverse events
(AEs) were also studied. AZL-M $40 \mathrm{mg}$ and $80 \mathrm{mg}$ reduced SBP significantly more than RAM $(P<0.001)$. Table 2 illustrates the conclusion that long-term treatment with AZL-M was more effective in reducing SBP when compared to RAM $10 \mathrm{mg}$. Additionally, AEs leading to discontinuation of treatment and occurrence of cough were less frequent with AZL-M $40 \mathrm{mg}$ and $80 \mathrm{mg}$ than with RAM $10 \mathrm{mg}$ (1.0\% and $1.4 \%$, versus $8.2 \%$ ).

\section{Rationale of combination therapy with other antihypertensives}

With the worldwide prevalence of hypertension affecting approximately $40 \%$ of adults aged 25 years and above, the need for dual therapy may be necessary for adequate blood pressure control. ${ }^{14}$ AZL-M can be combined with other classes of antihypertensive agents to achieve adequate blood pressure control. However, it is not recommended to be coadministered with aliskiren in patients with diabetes. ${ }^{3}$ In addition, AZL-M with aliskiren should be avoided in patients with renal impairment of glomerular filtration rate $<60 \mathrm{~mL} / \mathrm{min}^{3}$

The results from Antihypertensive and Lipid Lowering Treatment to Prevent Heart Attack Trial demonstrated that CLD based therapy was superior to lisinopril, amlodipine (AML), and doxazosin in preventing one or more forms of cardiovascular disease. ${ }^{15}$ The British National Institute of Clinical Excellence (NICE) guidelines prefers the use of CLD or indapamide if the use of a diuretic is warranted. ${ }^{16}$ CLD is a thiazide-like diuretic that is pharmacokinetically and pharmacodynamically different from hydrochlorothiazide (HCTZ). CLD and its metabolites have a longer half-life than hydrochlorothiazide and its metabolites. ${ }^{17,18}$ The halflife of CLD is approximately 42 hours and that of HCTZ is 6.5-9 hours. ${ }^{19,20}$ Additionally, available studies suggest that

Table 2 Change in clinic systolic blood pressure

\begin{tabular}{|c|c|c|c|}
\hline & $\begin{array}{l}\text { Azilsartan } \\
40 \mathrm{mg} \\
\mathrm{N}=294\end{array}$ & $\begin{array}{l}\text { Azilsartan } \\
80 \mathrm{mg} \\
\mathrm{N}=\mathbf{2 9 3}\end{array}$ & $\begin{array}{l}\text { Ramipril } \\
10 \mathrm{mg} \\
\mathrm{N}=\mathbf{2 9 2}\end{array}$ \\
\hline $\begin{array}{l}\text { Baseline } \\
\text { SBP mean }(\mathrm{mmHg})\end{array}$ & $160.9 \pm 0.5$ & $161.5 \pm 0.5$ & $|6| .4 \pm 0.5$ \\
\hline $\begin{array}{l}\Delta \text { week } 24 \mathrm{SBP}(\mathrm{mmHg}) \\
\Delta \text { versus ramipril } \\
(\mathrm{mmHg})(95 \% \mathrm{Cl})\end{array}$ & $\begin{array}{l}-20.6 \pm 0.9 \\
-8.4 \\
(-11.0,-5.8) \\
P<0.001\end{array}$ & $\begin{array}{l}-21.2 \pm 0.9 \\
-9.0 \\
(-11.7,-6.4) \\
P<0.001\end{array}$ & $-12.2 \pm 0.9$ \\
\hline
\end{tabular}

Note: From Bönner G, et al. Comparison of antihypertensive efficacy of the new angiotensin receptor blocker azilsartan medoxomil with ramipril. J Hypertens. 2010;28(e-Suppl A):e283(PP.16.II2). Reprinted with permission from Lippincott Williams \& Wilkins, Ltd., Copyright (c) $2011 .^{10}$

Abbreviations: $\mathrm{Cl}$, confidence interval; SBP, systolic blood pressure. 
$50 \mathrm{mg} \mathrm{HCTZ}$ is approximately equivalent to $25 \mathrm{mg}$ to $37 \mathrm{mg}$ CLD. ${ }^{18}$ The potency and extended duration of action of CLD is more likely to maintain net negative sodium balance and substantially add to the blood pressure lowering effect of the RAAS inhibitor. ${ }^{21}$ The manufacturer of AZL-M recognized the benefits of CLD, and the combination of AZL-M and CLD was approved in the US in December 2011. ${ }^{22}$

The combination of a $\mathrm{CCB}$ and an $\mathrm{ARB}$ is a rational approach. The benefits of $\mathrm{CCB} / \mathrm{ARB}$ combination therapy include additive blood pressure lowering effects and lower incidences of AEs. ${ }^{23-28}$ The efficacy of this combination has been investigated in clinical trials utilizing AML combined with OLM-M, telmisartan, or VAL. ${ }^{24-28}$ Currently, there are three FDA approved combinations of an ARB and a CCB: OLM-M and AML (Azor), VAL and AML (Exforge), and telmisartan and AML (Twynsta).

\section{Weber et al}

In this double blind placebo controlled trial, patients with stage 2 hypertension were randomized into one of three study groups. ${ }^{11}$ AML $5 \mathrm{mg}$ was used in combination with AZL-M $40 \mathrm{mg}$, AZL-M $80 \mathrm{mg}$, or placebo for 6 weeks. A total of 562 patients with stage 2 hypertension were evaluated in this study. The mean age of the participants was 58 years and $51 \%$ were men. The primary end point was change in 24 hour mean SBP as determined by ambulatory blood pressure monitoring. Clinic systolic and diastolic blood pressures, response rates, and AEs were secondary end points.

Table 3 illustrates that both AZL-M-AML combinations significantly lowered blood pressure when compared to the

Table 3 Change in clinic systolic blood pressure/diastolic blood pressure $(\mathrm{mmHg})$

\begin{tabular}{|c|c|c|c|}
\hline & \multicolumn{3}{|c|}{ Amlodipine 5 mg + } \\
\hline & $\begin{array}{l}\text { Placebo } \\
N=294\end{array}$ & $\begin{array}{l}\text { Azilsartan } \\
40 \mathrm{mg} \\
\mathrm{N}=\mathbf{2 9 3}\end{array}$ & $\begin{array}{l}\text { Azilsartan } \\
80 \mathrm{mg} \\
\mathrm{N}=292\end{array}$ \\
\hline $24 \mathrm{hr}$ mean ABPM, n (\%) & $166(90)$ & $165(87)$ & $166(88)$ \\
\hline Baseline & $153.9 / 92.9$ & $152.6 / 92.5$ & I54.4/93.| \\
\hline$\Delta$ & & $-24.8 /-15.3$ & $-24.5 /-15.4$ \\
\hline \multirow[t]{2}{*}{$\Delta$ versus placebo } & & $-11.2 /-7.5$ & $-10.9 /-7.7$ \\
\hline & & $P<0.001$ & $P<0.001$ \\
\hline Clinic, n (\%) & $179(97)$ & $187(99)$ & $183(97)$ \\
\hline Baseline & $166.1 / 94.0$ & $165.5 / 95.2$ & $165.4 / 94.5$ \\
\hline$\Delta$ & $-15.9 /-7.1$ & $-27.0 /-12.0$ & $-25.5 /-12.7$ \\
\hline \multirow[t]{2}{*}{$\Delta$ versus placebo } & & $-11.0 /-4.9$ & $-9.6 / 5.6$ \\
\hline & & $P<0.001$ & $P<0.001$ \\
\hline
\end{tabular}

Note: From Weber MA, et al. Antihypertensive efficacy of the novel angiotensin receptor blocker azilsartan medoxomil in combination amlodipine. J Hypertens. 2010;28(e-Suppl A):e279-e280(PP.16.99). Reprinted with permission from Lippincott Williams \& Wilkins, Ltd., Copyright (C) 201I."I

Abbreviation: ABPM, ambulatory blood pressure monitoring.
placebo-AML combination $(P<0.001)$. Response rates were $43 \%, 66 \%$, and $69 \%$ for the AML combinations with placebo, AZL-M $40 \mathrm{mg}$, or AZL-M $80 \mathrm{mg}$, respectively. Peripheral edema occurred more frequently with the placebo combination than with the AZL-M combination $(4.9 \%$ versus $2.1 \%$ ).

This study demonstrated that combining AML $5 \mathrm{mg}$ with AZL-M can be very efficacious in the treatment of patients with stage 2 hypertension. It can also be suggested that AZL-M was instrumental in decreasing the occurrence rate of peripheral edema, a common AE with the use of AML.

\section{Sica et al}

Sica et $\mathrm{al}^{12}$ used this 6-week randomized, double blind, placebo controlled trial to evaluate the efficacy of AZL-M combined with CLD for the treatment of stage 2 hypertension. Individuals were included in the study if they had a clinic SBP between $160 \mathrm{mmHg}$ and $190 \mathrm{mmHg}$, and a 24 hour mean SBP between $140 \mathrm{mmHg}$ and $180 \mathrm{mmHg}$. A total of 448 patients with similar 24 hour mean SBP measurements were randomized into one of three study groups. CLD $25 \mathrm{mg}$ was added to AZL-M $40 \mathrm{mg}$, AZL-M $80 \mathrm{mg}$, or placebo. The primary end point was change from baseline in 24 hour mean SBP as determined by ambulatory blood pressure monitoring.

Absolute reductions in 24 hour mean SBP were considerably higher in the study groups where CLD was added to AZL-M $40 \mathrm{mg}$ or $80 \mathrm{mg}(-31.7 \mathrm{mmHg}$ and $-31.3 \mathrm{mmHg}$, respectively) than in the study group combining CLD with placebo $(-15.9 \mathrm{mmHg} ; P<0.001)$. The addition of CLD to either available strength of AZL-M significantly decreased both clinic SBP and 24 hour mean SBP in stage 2 hypertensive patients.

\section{Bakris et al}

The first double blind study to compare the effects of the two thiazide diuretics in combination with an ARB utilized AZL-M. ${ }^{13}$ Bakris et al conducted a 10-week, double blind multicenter study that included more than 600 patients with moderate to severe hypertension. All patients received a daily dose of AZL-M $40 \mathrm{mg}$ for the first 2 weeks of the trial. For the following 4 weeks, the patients were randomized to either receive a fixed dose combination of AZL-M $40 \mathrm{mg}$ and CLD $12.5 \mathrm{mg}$, or AZL-M $40 \mathrm{mg}$ coadministered with hydrochlorothiazide $12.5 \mathrm{mg}$. During weeks 7 through 10 , the diuretics were titrated to $25 \mathrm{mg}$ for the patients who did not reach target blood pressure. The primary end point was change in clinic SBP from baseline. 
Six weeks after the beginning of the study, the reduction in clinic SBP was higher in the CLD combination group than in the HCTZ group $(-35.1 \mathrm{mmHg}$ versus $-29.5 \mathrm{mmHg})$. The majority of patients in the CLD group achieved the target clinic blood pressure in comparison to the HCTZ group (64.1\% versus $45.9 \% ; P<0.001)$. The mean difference in 24 hour ambulatory SBP at week 6 was $-5.8 \mathrm{mmHg}$ in favor of the AZL-M and CLD group. Fifteen percent more patients in the HCTZ study group required the increase in diuretic dose than in the CLD group. The fixed combination of AZL-M and CLD significantly decreased clinic blood pressure measurements and 24 hour mean SBP more than AZL-M with HCTZ.

The two additional studies that will be discussed were published after the approval of AZL-M.

\section{Sica et al}

This 8-week randomized, double blind factorial study compared the efficacy and safety of fixed dose combinations of AZL-M and CLD with the individual monotherapies. ${ }^{29}$ A total of 1,714 participants were randomized to AZL-M $0 \mathrm{mg}, 20 \mathrm{mg}, 40 \mathrm{mg}$, or $80 \mathrm{mg}$ and/or CLD $0 \mathrm{mg}, 12.5 \mathrm{mg}$, or $25 \mathrm{mg}$. The study participants were men and women 18 years of age and older with a SBP ranging from $160 \mathrm{mmHg}$ to $190 \mathrm{mmHg}$. The mean age was 57 years, $47 \%$ were men, and $20 \%$ were black. The primary end point was the change in trough SBP by ambulatory blood pressure monitoring at week 8.

Each AZL-M/CLD fixed dose combination reduced the trough SBP significantly more than CLD or AZL-M alone $(P<0.001)$. In patients with stage 2 hypertension, treatment with a AZL-M and CLD fixed dose combination resulted in greater SBP reduction when compared to either agent alone.

\section{Cushman et al}

In this large, forced titration active comparator study, AZL-M plus CLD was compared to OLM-M plus HCTZ. ${ }^{30}$ This study evaluated the antihypertensive efficacy, safety, and tolerability of the two combinations. The design was a randomized, three arm, double blind, 12 week study of 1,071 participants. The three arms were AZL-M/CLD $20 \mathrm{mg} / 12.5 \mathrm{mg}$ forced titrated to $40 \mathrm{mg} / 25 \mathrm{mg}$, AZL-M/CLD $40 \mathrm{mg} / 12.5 \mathrm{mg}$ forced titrated to $80 \mathrm{mg} / 25 \mathrm{mg}$, and OLM-M//HCTZ $20 \mathrm{mg} / 12.5 \mathrm{mg}$ forced titrated to $40 \mathrm{mg} / 25 \mathrm{mg}$. The force titration occurred at weeks 4 and 8 . The mean age was 57 years, $59 \%$ were men, $73 \%$ were white, and $22 \%$ were black. Baseline clinic blood pressure was $165 / 96 \mathrm{mmHg}$. The primary end point was a change from baseline in trough, seated, and clinic SBP at week 12 .

The changes in clinic SBP at week 12 were significantly greater in the AZL-M/CLD arms than in the OLM-M/HCTZ arm $(-42.5 \pm 0.8,-44.0 \pm 0.8$, and $-37.1 \pm 0.8 \mathrm{mmHg}$; $P<0.001)$. This study has demonstrated that ALZ-M/CLD fixed dose combinations have superior antihypertensive efficacy when compared to the maximum approved dose of OLM-M/HCTZ.

\section{Safety and tolerability}

The safety of AZL-M (doses of 20, 40, or $80 \mathrm{mg}$ ) has been evaluated in 4,814 patients in clinical trials with durations up to 1 year. ${ }^{3}$ AZL-M was well tolerated with an overall incidence of adverse reactions similar to placebo. Diarrhea was reported in up to $2 \%$ of patients on AZL-M $80 \mathrm{mg}$ versus $0.5 \%$ of those on placebo. Other side effects including nausea, asthenia, fatigue, muscle spasm, dizziness, and cough were reported with an incidence of $\geq 0.3 \%$ versus placebo in more than 3,300 patients. Small increases in serum creatinine were observed in patients on AZL-M $80 \mathrm{mg}$. Patients $>75$ years of age or those patients with moderate or severe renal impairment are more likely to report serum creatinine increases. Low hemoglobin $(0.2 \%)$, hematocrit $(0.4 \%)$, and red blood cell counts $(0.3 \%)$ were observed in AZL-M treated patients versus placebo $(0 \%)$.

During the second and third trimester of pregnancy, agents that affect the RAAS reduce fetal renal function and increase fetal morbidity and mortality. In addition to other ARBs and ACE inhibitors, AZL-M is not recommended during pregnancy and is pregnancy category D. AZL-M was excreted at low concentrations in the milk of lactating rats. The excretion possibility for human milk is currently unknown.

No safety and efficacy data is available in patients under 18 years of age. No dose adjustment is necessary for elderly patients, for patients with renal impairment, or in patients with mild to moderate hepatic impairment. It should be noted that AZL-M has not been studied in patients with severe hepatic impairment.

AZL-M is metabolized by CYP2C9. Therefore, caution should be advised when AZL-M is administered with strong modulators of this enzyme. Nonsteroidal anti-inflammatory drugs and cyclooxygenase- 2 inhibitors may attenuate the antihypertensive effects of ARBs. Concurrent use may cause worsening of renal function in patients who are elderly, volume depleted, or who have baseline compromised renal 
function. ${ }^{31}$ AZL-M does not appear to have any clinically significant drug interactions with AML, antacids, CLD, digoxin, fluconazole, glyburide, ketoconazole, metformin, pioglitazone, and warfarin. ${ }^{3}$

\section{Patient focused perspectives such as quality of life, patient satisfaction/ acceptability, adherence, and uptake}

A patient's quality of life, satisfaction, and adherence regarding medications are vital components to consider when selecting a medication regimen. Poor adherence to medical treatment is a well-recognized problem in the literature. ${ }^{32-36}$ In the US, nonadherence to medications causes 125,000 deaths annually and accounts for $10 \%$ to $25 \%$ of hospital and nursing home admissions ${ }^{37}$ Therefore, nonadherence to medications is one of the most expensive disease categories.

The complexity of a treatment regimen can affect adherence. Strategies used to simplify a regimen have already become standardized practices. Adherence improves remarkably when a patient is prescribed a pill that can be taken once a day. This can be accomplished with a longer acting drug or with a pill that combines more than one drug. ${ }^{38}$

Medication side effects are highly prevalent and significantly associated with medication nonadherence. Nonadherence is significantly associated with increased health care resource use. Prevention, identification, and effective management of medication induced side effects are important to maximize adherence and reduce health resource use. ${ }^{39}$

AZL-M has the potential to help decrease patient nonadherence due to pill burden and side effects. The pharmacodynamic profile of AZL-M allows for once a day dosing, which may increase patients' medication adherence. The combination of AZL-M and CLD (Edarbyclor) provides substantial blood pressure lowering which can potentially obviate the need for the addition of other agents. Another advantage of AZL-M is that it should not affect bradykinin levels, thereby reducing the incidence of cough which is often observed with ACE inhibitors. In addition, the study conducted by Weber et al demonstrated that when AZL-M is combined with AML, the peripheral edema was reduced in comparison to AML alone $(2.1 \%$ versus $4.9 \%) .{ }^{11}$

Currently, there are three ARBs that are available as generic products. They include irbesartan, losartan, and eprosartan. The average wholesale price for a 30-day supply of the maximum dose of each ARB is: $\$ 92$ for irbesartan, \$92 for losartan, \$103 for eprosartan, \$107 AZL-M, \$161 for telmisartan, \$167 for OLM-M, \$183 for VAL, and \$105 for candesartan. ${ }^{40}$ It appears that the generic products are less expensive, however, the brand name ARB, AZL-M, may be pharmacoeconomical for most patients based on the price of the other brand name ARBs.

\section{Conclusion}

Hypertension is a risk factor for cardiovascular disease and having a strict or controlled blood pressure is critical in reducing or preventing cardiovascular disease. Globally, cardiovascular disease accounts for approximately 17 million deaths a year, nearly one third of the total number of deaths. ${ }^{12}$ Of these, complications of hypertension account for 9.4 million deaths worldwide every year. ${ }^{12}$

The NICE guidelines recommend an ARB as a first line option in patients younger than 55 years of age. ${ }^{14}$ The seventh Report of the Joint National Committee and European guidelines recommend ARBs as preferred alternatives to ACE inhibitors for patients with various comorbidities or cardiovascular risk factors..$^{41,42}$

AZL-M is the latest ARB approved for the treatment of hypertension. When compared to other ARBs (OLM-M and VAL) and an ACE inhibitor (RAM), AZL-M proved to be more effective at reducing blood pressure. ${ }^{7,8,10}$ The greater blood pressure reduction observed may be related to the pharmacologic profile, including slowed $\mathrm{AT}_{1}$ receptor dissociation and improved receptor specificity. The combination of AZL-M and CLD has proven to significantly lower blood pressure more than AZL-M and HCTZ. Therefore, if a diuretic is needed for additional blood pressure reduction, CLD is the more appropriate option to add to AZL-M.

AZL-M is available in $40 \mathrm{mg}$ and $80 \mathrm{mg}$ tablets. The recommended initial dose is $80 \mathrm{mg}$ daily. Prescribers should consider $40 \mathrm{mg}$ daily for patients with volume depletion or who are on high dose diuretics. Currently, AZL-M should be considered as an alternative for stage 1 and 2 hypertension or as an adjunctive therapy when preferred agents fail to control blood pressure.

\section{Disclosure}

The authors report no conflict of interest in this work.

\section{References}

1. Go AS, Mozaffarian D, Roger VL, et al; American Heart Association Statistics Committee and Stroke Statistics Subcommittee. Heart disease and stroke statistics - 2013 update: a report from the American Heart Association. Circulation. 2013;127:e6-e245.

2. Farley TA, Dalal MA, Mostashari F, Frieden TR. Deaths preventable in the U.S. by improvements in use of clinical preventive services. $\mathrm{Am}$ J Prev Med. 2010;38:600-609. 
3. Edarbi (azilsartan medoxomil) [prescribing information]. Osaka, Japan: Takeda Pharmaceutical Company Limited; 2012.

4. Saseen JJ, Maclaughlin EJ. Hypertension. In: Dipiro JT, Tablbert RL, Yee GC, Matzke GR, Wells BG, Possey LM, editors. Pharmacotherapy: A Pathophysiologic Approach, $8^{\text {th }}$ ed. New York: McGraw-Hill; 2011: 101-135.

5. Burnier M. Angiotensin II type 1 receptor blockers. Circulation. 2001;103:904-912.

6. Kurtz TW, Kajiya T. Differential pharmacology and benefit/risk of azilsartan compared to other sartans. Vasc Health Risk Manag. 2012;8: 133-143.

7. Bakris GL, Sica D, Weber MA, et al. The comparative effects of azilsartan medoxomil and olmesartan on ambulatory and clinic blood pressure. J Clin Hypertens (Greenwich). 2011;13:81-88.

8. White WB, Weber MA, Sica D, et al. Effects of the angiotensin receptor blocker azilsartan medoxomil versus olmesartan and valsartan on ambulatory and clinic blood pressure in patients with stages 1 and 2 hypertension. Hypertension. 2011;57(3):413-420.

9. Sica D, White WB, Weber MA, et al. Comparison of the novel angiotensin II receptor blocker azilsartan medoxomil vs valsartan by ambulatory blood pressure monitoring. J Clin Hypertens (Greenwich). 2011;13(7):467-472.

10. Bönner G, Bakris GL, Sica D, et al. Comparison of antihypertensive efficacy of the new angiotensin receptor blocker azilsartan medoxomil with ramipril. J Hypertens. 2010;28(e-Suppl A):e283(PP.16.112).

11. Weber MA, White WB, Sica D, et al. Antihypertensive efficacy of the novel angiotensin receptor blocker azilsartan medoxomil in combination amlodipine. J Hypertens. 2010;28(e-Suppl A):e279-e280 (PP.16.99).

12. Sica D, Bakris GL, White WB, et al. New angiotensin II receptor blocker azilsartan medoxomil coadministered with chlorthalidone provides potent blood pressure reduction in stage 2 hypertension (Abstract). J Clin Hypertens (Greenwich). 2010;12(Suppl 1): A114.

13. Bakris G, Sica D, White WB, et al. Antihypertensive efficacy of hydrochlorothiazide vs chlorthalidone combined with azilsartan medoxomil. Am J Med. 2012;125(12):1229. e1-1229. e10.

14. World Health Organization. A Global Brief on Hypertension: Silent Killer, Global Public Health Crisis. Geneva: World Health Organization; 2013. Available from: http://www.who.int/ cardiovascular_diseases/publications/global_brief_hypertension/en/. Accessed April 26, 2013.

15. ALLHAT Officers and Coordinators for the ALLHAT Collaborative Research Group. The Antihypertensive and Lipid-Lowering Treatment to Prevent Heart Attack Trial. Major outcomes in high risk hypertensive patients randomized to angiotensin-converting enzyme inhibitor or calcium channel blocker vs diuretic. The Antihypertensive and LipidLowering Treatment to Prevent Heart Attack Trial (ALLHAT). JAMA. 2002;288:2981-2997.

16. Krause T, Lovibond K, Caulfield M, McCormack T, Williams B; Guideline Development Group. Management of hypertension: summary of NICE guidance. BMJ. 2011;343:d4891.

17. Ernst ME, Carter BL, Goerdt CJ, et al. Comparative antihypertensive effects of hydrochlorothiazde and chlorthalidone on ambulatory and office blood pressure. Hypertension. 2006;47:352-358.

18. Carter BL, Ernst ME, Cohen JD. Hydrochlorothiazide versus chlorthalidone: evidence supporting their interchangeability. Hypertension. 2004:43:4-9.

19. Howes LG, Conway EL, Phillips PA, Broadbear J, Drummer OH, Louis WJ. Pharmacokinetic comparison of a combination tablet of enalapril and hydrochlorothiazide with enalapril and hydrochlorothiazide tablets administered together and separately. Biopharm Drug Dispos. 1991;12:447-455.

20. Giudicelli JF, Richer C, Mattei A. Pharmacokinetics and biological effects of captopril and hydrochlorothiazide after acute and chronic administration either alone or in combination in hypertensive patients. Br J Clin Pharmacol. 1987;23(Suppl 1):51S-63S.
21. Sica DA. Chlorthalidone: has it always been the best thiazide-type diuretic? Hypertension. 2006;47:321-322.

22. Takeda Pharmaceutical Company Limited. FDA approves edarbyclor (azilsartan medoxomil and chlorthalidone) for the treatment of hypertension [press release]. Deerfield, IL and Osaka, Japan: Takeda Pharmaceutical Company Limited; 2011 [December 21]. Available from: http://www.takeda.com/news/2011/20111221_3930.html. Accessed April 23, 2013.

23. Makani H, Bangalore S, Romero J, Bever-Pinzon O, Messerili FH. Effect of renin-angiotensin system blockade on calcium channgel blocker associated peripheral edema. Am J Med. 2001;124(2): 128-135.

24. Ogawa H, Kim-Mitsuyama S, Matsui K, et al; OlmeSartan and Calcium Antagonists Randomized (OSCAR) Study Group. Angiotensin II receptor blocker-based therapy in Japanese elderly, high-risk, hypertensive patients. Am J Med. 2012;125(10):981-990.

25. Chrysant SG, Melino M, Karki S, Lee J, Heyrman R. The combination of olmesartan medoxomil and amlodipine besylate in controlling high blood pressure: $\mathrm{COACH}$, a randomized, double-blind, placebocontrolled, 8-week factorial efficacy and safety study. Clin Ther. 2008;30(4):587-604.

26. Littlejohn TW III, Majul CR, Olvera R, et al; study investigators. Telmisartan plus amlodipine in patients with moderate or severe hypertension: results from a subgroup analysis of a randomized, placebo-controlled, parallel group, $4 \times 4$ factorial study. Postgrad Med. 2009;121(2):5-14.

27. Philipp T, Smith TR, Glazer R, et al. Two multicenter, 8-week, randomized, double-blind, placebo-controlled, parallel-group studies evaluation the efficacy and tolerability of amlodipine and valsartan in combination and as monotherapy in adult patients with mild to moderate essential hypertension. Clin Ther. 2007;29(4):563-580.

28. Schunkert H, Glazer RD, Wernsing M, et al. Efficacy and tolerability of amlodipine/valsartan combination therapy in hypertensive patients not adequately controlled on amlodipine monotherapy. Curr Med Res Opin. 2009;25(11):2655-2662.

29. Sica D, Bakris GL, White WB, et al. Blood pressure lowering efficacy of the fixed-dose combination of azilsartan medoxomil and chlorthalidone: a factorial study. J Clin Hypertens (Greenwich). 2012;14: 284-292.

30. Cushman WC, Bakris GL, White WB, et al. Azilsartan medoxomil plus chlorthalidone reduces blood pressure more effectively than olmesartan plus hydrochlorothiazide in stage 2 systolic hypertension. Hypertension. 2012;20:310-318.

31. Lam S. Azilsartan: a new approved angiotensin II receptor blocker. Cardiol Rev. 2011;19(6):300-304.

32. Haynes RB. Introduction. In: Haynes RB, Taylor DW, Sackett DL, editors. Compliance in Health Care. Baltimore, MD: Johns Hopkins University Press; 1979:1-18.

33. Blackwell B. Drug therapy: patient compliance. $N$ Engl J Med. 1973;289:249-252.

34. Davis MS. Variation in patients' compliance with doctors' orders: medical practice and doctor-patient interaction. Psychiatry Med. 1971;2(1):31-54.

35. Osterberg L, Blaschke T. Drug therapy: adherence to medication. NEngl J Med. 2005;353:487-497.

36. Karter AJ, Parker MM, Moffet HH, Ahmed AT, Schmittdiel JA, Selby JV. New prescription medication gaps: a comprehensive measure of adherence to new prescriptions. Health Serv Res. 2009;44:1640-1661.

37. Smith DL. Compliance packaging: a patient educational tool. Am Pharm. 1989;NS29(2):42-45, 49-53.

38. Morningstar BA, Sketris IS, Kephart GC, Sclar DA. Variation in pharmacy prescription refill adherence measures by type of oral antihyperglycaemic drug therapy in seniors in Nova Scotia, Canada. J Clin Pharm Ther. 2002;27:213-220.

39. Dibonaventura M, Gabriel S, Dupclay L, Gupta S, Kim E. A patient perspective of the impact of medication side effects on adherence: results of a cross-sectional nationwide survey of patients with schizophrenia. BMC Psychiatry. 2012;12:20. 
40. McKesson. San Francisco, California. Available from: https://connect. mckesson.com (password-protected). Accessed April 29, 2013.

41. Chobanian AV, Bakris GL, Black HR, et al; National Heart, Lung, and Blood Institute Joint National Committee on Prevention, Detection, Evaluation, and Treatment of High Blood Pressure; National High Blood Pressure Education Program Coordinating Committee. The Seventh Report of the Joint National Committee on prevention, detection, evaluation, and treatment of high blood pressure: the JNC 7 Report. JAMA. 2003;289(19):2560-2571.
42. Mancia G, Laurent S, Agabiti-Rosei E, et al; European Society of Hypertension. Reappraisal of European guidelines on hypertension management: a European Society of Hypertension Task Force document J Hypertens. 2009;27(11):2121-2158.

Research Reports in Clinical Cardiology

\section{Publish your work in this journal}

Research Reports in Clinical Cardiology is an international, peerreviewed, open access journal publishing original research, reports, editorials, reviews and commentaries on all areas of cardiology in the clinic and laboratory. The manuscript management system is completely online and includes a very quick and fair peer-review system.
Visit http://www.dovepress.com/testimonials.php to read real quotes from published authors. 